\title{
PENGARUH PEMBELAJARAN OUTDOOR STUDY TERHADAP HASIL BELAJAR IPS SISWA MI
}

\author{
Risma Dwi Arisona ${ }^{1)}$, Ahmad Farid Utsman ${ }^{2)}$ \\ IAI Sunan Giri Bojonegoro \\ Jalan Ahmad Yani No 10 Bojonegoro \\ Email: rismaarisona20@gmail.com ${ }^{1)}$, faridbjn90@gmail.com ${ }^{2)}$
}

\begin{abstract}
Abstrak - Penelitian ini bertujuan mengetahui pengaruh pembelajaran Outdoor Study terhadap hasil belajar IPS Siswa MI. Penelitian ini merupakan penelitian eksperimen semu (quasi experiment) dengan desain penelitian Non equivalent control group design. Subjek dalam penelitian ini adalah siswa kelas V MI Al Huda Kalianyar Bojonegoro tahun ajaran 2015/2016. Kelas V A sebagai kelas eksperimen dan kelas V B sebagai kelas kontrol. Instrumen penilaian hasil belajar menggunakan tes esai. Hasil penilaian berupa data gain score yang merupakan selisih nilai pre-test dan post-test dianalisis menggunakan $t$-test dengan bantuan program SPSS 16.0 for Windows. Berdasarkan hasil analisis uji-t diperoleh nilai p-level lebih kecil $0,05(\mathrm{p}<0,05)$, yaitu 0,000 . Hasil ini menunjukkan bahwa $\mathrm{H}_{0}$ ditolak dan $\mathrm{H}_{1}$ diterima. Jadi, model pembelajaran outdoor study berpengaruh terhadap hasil belajar IPS siswa MI. Hal tersebut dapat terlihat dari rata-rata gain score kelas eksperimen sebesar 35,16 lebih tinggi daripada kelas kontrol yang hanya sebesar 14,04.
\end{abstract}

Kata Kunci: Pembelajaran Outdoor Study, Hasil Belajar, IPS

\begin{abstract}
The aim of the study is to find out the effect of applying outdoor study on the learning output of the Madrasah Ibtidaiyah students in Social Studies. This study is quasi experiment with non equivalent control group research design. The subjects of this study are the five graders of MI Al Huda Kalianyar Bojonegoro. They are in 2015/2016 academic year. The five graders class $A$ is the experimental group and the five graders class $B$ is the control group. The instrument used to measure the learning output is essay test. The result of the study is in the form of gain score data whis is the gap between the score of pre-test and post-test to be then analyzed by using t-test with SPSS 16.0 for Windows.Based on the result of the t-test, the p-level is 0.05 lower ( $p<0.05)$. It is 0.000. The result shows that $H_{0}$ is rejected and $H_{1}$ is accepted. So, it shows that the outdoor study brings significant effect on the social studies output of the Madrasah Ibtidaiyah students. It can be seen from the average gain score of experimental group which has 35,16 higher score than the control group which gains only 14,04.
\end{abstract}

Keywords: Outdoor Study, Outcome, and Social Studies 


\section{PENDAHULUAN}

Pembelajaran kontekstual berpandangan bahwa pembelajaran kontekstual merupakan pembelajaran yang memungkinkan siswa dapat menguatkan, memperluas, menerapkan pengetahuan, dan keterampilan akademiknya baik di dalam maupun di luar kelas, serta peserta didik dapat memecahkan berbagai permasalahan di sekitarnya. Pembelajaran kontekstual merupakan perpaduan banyak praktik pembelajaran yang pada akhir-akhir dianggap paling baik dan relevan bagi peningkatan keterampilan hidup siswa. Hal itu dimaksudkan untuk memperkaya relevasi dan penggunaan fungsi pendidikan bagi siswa.

Pembelajaran kontekstual di dalam kelas, para guru cenderung berperan sebagai fasilitator yang "membantu" siswa mencapai tujuan belajar. Guru lebih banyak berurusan dengan strategi daripada memberi informasi, guru dituntut mengelola kelas yang merupakan sebuah tim secara kooperatif menemukan sesuatu yang baru bagi siswa. Dalam hal ini siswa mendapatkan "pengetahuan baru" yang berasal dari menemukan sendiri atas dasar pengamatan (penelitian lapangan) bukan dari apa kata guru. Dimana guru membantu menghubungkan pengetahuan lama siswa (etnry behavior) dengan pengetahuan "baru" di dapatkannya, sehingga guru sebagai yang mengarahkan dan memfasilitasi belajar serta memberikan kesempatan kepada siswa untuk menemukan dan menerapkan idenya. Dengan demikian, strategi belajar lebih dipentingkan daripada hasil belajarnya (Nurhadi, 2002). Lebih lanjut, dikatakan pula bahwa pembelajaran kontekstual terkait dengan interaksi/hubungan yang erat antara peserta didik dengan pengalaman sesungguhnya. Dalam hal ini siswa mengalami apa yang dipelajarinya bukan hanya apa yang diketahuinya. Atas pendapat tersebut pembelajaran kontekstual terjadi apabila siswa menerapkan dan mengalami apa yang sedang diajarkan dengan mengacu pada masalahmasalah dunia nyata yang berhubungan dengan peran dan tanggung jawab peserta didik sebagai anggota keluarga, warga negara, siswa, dan tenaga kerja.

Memperkuat pendapat diatas, Susilo (2001:3) memberikan penegasan bahwa penggunaan pembelajaran kontekstual memiliki potensi untuk tidak hanya mengembangkan ranah pengetahuan dan keterampilan siswa, tetapi juga mengembangkan sikap, nilai, dan kreativitas siswa dalam memecahkan masalah yang terkait dengan kehidupannya. Demikian halnya Rostana (2004:4) menegaskan bahwa pembelajaran semacam itu bertujuan membekali siswa dengan pengetahuan yang secara fleksibel dapat diterapkan (ditransfer) dari satu permasalahan ke permasalahan lain dan dari satu konteks ke konteks lainnya.

Pembelajaran outdoor study merupakan pembelajaran kontekstual yang mengarah pada kecakapan hidup (life skill) siswa. Pembelajaran outdoor study berasumsi bahwa siswa belajar mengonstruksi konsep melalui pengalaman hidupnya sendiri dan bukan menghafal konsep. Untuk itu, dalam pembelajarannya selalu dikaitkan dengan konteks kehidupan siswa, 
tujuannya agar siswa mampu berpartisipasi dalam penanggulangan permasalahan lingkungan hidup yang terdapat pada materi IPS kelas V SD/MI

Menurut Nurhadi (2002:5) dalam pembelajaran kontekstual dikenal ada 15 kata kunci, yakni: (1) belajar dalam dunia nyata, (2) mengutamakan pengalaman nyata, (3) berfikir tingkat tinggi, (4) berpusat pada siswa, (5) siswa kritis, aktif, dan kreatif, (6) pengetahuan yang didapat bermakna bagi kehidupan siswa, (7) dekat dengan kehidupan nyata, (8) terjadi perubahan perilaku, (9) siswa praktik langsung bukan sekedar menghafal, (10) learning bukan teaching, (11) pendidikan (education) bukan pengajaran (instruction), (12) pembentukan manusia secara utuh, (13) memecahkan masalah, (14) siswa "acting" guru mengarahkan/sebagai fasilitator, (15) Hasil belajar diukur dengan berbagai cara/kegiatan, bukan hanya dengan tes tertulis atau lisan.

Salah satu aplikasi pembelajaran kontekstual yang dianggap dapat meningkatkan hasil belajar siswa adalah melalui pengamatan langsung kepada objek sesungguhnya (outdoor study). Pembelajaran Outdoor Study dapat dilakukan dengan pengamatan kondisi alam (SDA) serta kondisi sosial, ekonomi, dan budaya masyarakat (SDM) yang ada di sekitar sekolah di mana siswa berada. Dengan demikian, pembelajaran tersebut bukan sekedar transfer ilmu antara guru dan murid, melainkan membebaskan dan melepaskan pikiran siswa untuk merasakan, mengamati, menemukan, dan menyimpulkan analisis secara pribadi, dan guru berperan sebagai pembimbing, fasilitator, dan motivator yang membantu dalam proses belajar. Belajar semacam itu sebagai pola penerapan self direct learning di mana siswa dapat dengan bebas mengonstruksi apa yang dilihat, diamati, ditulis dan dipresentasikan berdasarkan pengalaman belajarnya sendiri, sehingga dapat mengembangkan kecakapan hidup siswa.

Pembelajaran outdoor merupakan salah satu pembelajaran yang menekankan pada pengalaman seseorang yang diperoleh melalui observasi langsung di lapangan. Pembelajaran tersebut layak diterapkan pada mata pelajaran IPS sebagai salah satu cabang ilmu terapan yang mempunyai kandungan ilmu yang luas berupa interaksi antara kondisi fisik dengan manusia. Mata pelajaran IPS mengkaji seperangkat peristiwa, fakta, konsep, dan generalisasi yang berkaitan dengan isu sosial (Depdiknas, 2006). Oleh sebab itu, pada mata pelajaran IPS dirancang untuk mengembangkan pengetahuan, pemahaman, dan kemampuan analisis terhadap kondisi sosial masyarakat dalam memasuki kehidupan masyarakat yang dinamis.

Mata pelajaran IPS bertujuan agar siswa memiliki kemampuan 1) mengenal konsepkonsep yang berkaitan dengan kehidupan masyarakat dan lingkungannya, 2) memiliki kemampuan dasar untuk berpikir kritis dan logis, rasa ingin tahu, inkuiri, memecahkan masalah, dan keterampilan berkehidupan sosial, 3)memiliki komitmen dan kesadaran terhadap nilai-nilai sosial dan kemanusiaan, dan 4) memiliki kemampuan berkomunikasi, 
bekerjasama dan kompetensi dalam mayarakat majemuk di tingkat lokal, nasional, dan global.

Kaitannya mata pelajaran IPS dengan outdoor study, diperlukan beberapa urutan tahapan kegiatan. Tahap itu antara lain sebagai berikut: (1) mengamati; (2) mengklasifikasikan; (3) mengkomunikasikan; (4) mengukur; (5) memprediksi; dan (6) menyimpulkan; serta (7) menulis laporan hasil studi (Gage and Berliner, 1985).

Setiap hasil pemahaman siswa selalu menunjukkan sejauh mana taraf keberhasilan guru dan belajar siswa secara tepat (valid), dapat dipercaya (reliable), dan dapat dipertanggungjawabkan (responsible). Untuk mengukur hal tersebut, dalam sistem pendidikan nasional rumusan tujuan kurikuler maupun tujuan instruksional menggunakan ukuran domain Bloom berupa kognitif, afektif, dan psikomotor yang secara garis besar dibagi menjadi tiga ranah yang terkenal dengan Taksonomi Bloom. Namun demikian, dalam praktiknya ketiga ranah tersebut dilakukan pengukuran secara komprehensif, di mana cenderung hanya pada pengukuran ranah afektif. Penilaian dilakukan dengan tes hasil belajar siswa dan belum pernah mengukur ranah life skill, setidaknya dalam bidang pembelajaran IPS di sekolah.

Untuk membelajarkan outdoor pada beberapa topik Geografi diperlukan motivasi dan keaktifan siswa dalam memahami konsep melalui rentetan peristiwa (pengalaman) pembelajaran yang diperoleh langsung di lapangan (outdoor). Belajar terjadi bila perubahan dalam bentuk tingkah laku siswa dapat diamati langsung oleh guru. Dengan demikian, dalam pola pembelajaran semacam itu guru berperan sebagai pembimbing, fasilitator, motivator, dan sekaligus evaluator secara langsung yang mengajak siswa belajar di luar kelas dan membebaskan siswa mengembangkan aspek kognitif, afektif, dan psikomotor dalam dirinya.

Penerapan pembelajaran Outdoor Study akan memudahkan guru dalam menumbuhkan motivasi belajar siswa. Diketahui bahwa motivasi merupakan unsur penting dalam proses pembelajaran yang dipandang sebagai dorongan mental untuk menggerakkan dan mengarahkan perilaku manusia, termasuk perilaku belajar. Motivasi terdapat keinginan, harapan, kebutuhan, tujuan, sasaran, dan insentif. Kondisi kejiwaan semacam inilah yang mengaktifkan, menggerakkan, menyalurkan, dan mengarahkan sikap dan perilaku belajar individu.

Adanya dorongan mental dalam diri siswa secara otomatis akan berimbas langsung pada perilaku fisik siswa yang ditunjukkan ketika siswa mengamati, memperhatikan, berdiskusi, memecahkan masalah, dan mengadakan perbandingan antara buku teks dan kenyataan di lapangan, sampai pada waktu membuat kesimpulan akhir. Pada kegiatan pembelajaran tersebut siswa tampak antusias dalam melakukannya.

Berdasarkan hal tersebut di atas diketahui bahwa dorongan mental (motivasi) dan aktifitas fisik (keaktifan) akan berpengaruh langsung pada hasil belajar siswa. Di antara ketiganya 
terdapat keterkaitan kuat. Karena hasil belajar merupakan puncak dari proses belajar mengajar. Hasil belajar pada hakekatnya adalah perubahan tingkah laku sebagai hasil dari proses belajar mengajar. Perubahan itu dapat berupa pengetahuan, pemahaman, keterampilan, dan sikap.

Berdasarkan uraian di atas, tujuan penelitian ini adalah untuk mengetahui pengaruh pembelajaran outdoor study terhadap hasil belajar IPS siswa MI pada Kompetensi Dasar menunjukkan perilaku peduli, gotongroyong, tanggungjawab dalam berpartisipasi penanggulangan permasalahan lingkungan hidup

\section{METODE PENELITIAN}

Penelitian ini dirancang dalam bentuk eksperimen kuasi menggunakan non-equivalent (pre-test dan post-test) control-group design untuk mengetahui pengaruh pembelajaran outdoor study pada Kompetensi Dasar menunjukkan perilaku peduli, gotong royong, tanggungjawab dalam berpartisipasi penanggulangan permasalahan lingkungan hidup terhadap hasil belajar IPS siswa MI. Lokasi penelitian di MI Al Huda Kalianyar Bojonegoro yang beralamat di Jalan Letda Nur Hasyim Gg. Basar Desa Kalianyar Kapas Bojonegoro 62181. Populasi penelitian siswa kelas V MI Nurul Huda Bojonegoro, sedangkan sampel penelitian, yaitu kelas V A sebagai kelas kontrol sebanyak 30 siswa dan V B sebagai kelas eksperimen sebanyak 30 siswa. Analisis data menggunakan t-test yang dibantu dengan program SPSS by Windows.

\section{HASIL DAN PEMBAHASAN}

Pengujian hipotesis penelitian ini menggunakan data gain score. Gain score diperoleh dengan cara mengurangi nilai posttest dengan nilai pretest. Rata-rata gain score kelas eksperimen sebesar 35,16 dan kelas kontrol sebesar 14,04. Dengan demikian, rata-rata gain score kelas ekperimen lebih tinggi daripada kelas kontrol dengan selisih 21,11. Berikut tabel 1 perolehan pre-test, post-test, dan gain score.

Tabel 1. Nilai Rata-rata pre-test, post-test, dan gain score

\begin{tabular}{|c|c|c|c|c|c|}
\hline Kelas & $\begin{array}{c}\text { Pre- } \\
\text { test }\end{array}$ & $\begin{array}{c}\text { Kriter } \\
\text { ia }\end{array}$ & $\begin{array}{c}\text { Post- } \\
\text { test }\end{array}$ & $\begin{array}{c}\text { Kriter } \\
\text { ia }\end{array}$ & $\begin{array}{c}\text { Gain- } \\
\text { score }\end{array}$ \\
\hline Eks & 50,44 & $\begin{array}{c}\text { Renda } \\
\text { h } \\
\text { Renda } \\
\text { h }\end{array}$ & 85,60 & Tinggi & 35,16 \\
Kon & 52,15 & 66,62 & Cukup & 14,05 \\
\hline \multicolumn{6}{|c|}{ Hasil analisis data gain score dengan }
\end{tabular}
dengan menggunakan independen sample t test (uji-t) pada pembelajaran outdoor study terhadap hasil belajar IPS siswa MI data p-level lebih kecil dari $0,05 \quad(p<0,05)$ yaitu dengan signifikansi 0,00. Data tersebut menunjukkan bahwa ada pengaruh pembelajaran outdoor study terhadap hasil belajar IPS siswa MI.

$$
\text { Pembelajaran outdoor study }
$$
berpengaruh terhadap hasil belajar IPS siswa MI pada Kompetensi Dasar Menunjukkan perilaku peduli, gotongroyong, tanggungjawab dalam berpartisipasi penanggulangan permasalahan lingkungan hidup disebabkan: pertama, pembelajaran outdoor study mengarahkan siswa untuk belajar di luar kelas yang sesuai dengan konteks. Jonassen (1991) (dalam Sumarmi 2012: 172) menyatakan bahwa "belajar lebih efektif bila terjadi di dalam konteks". Pembelajaran 
dalam penelitian ini menciptakan lingkungan belajar yang riildan relevan dengan materi permasalahan lingkungan hidup yang akan memudahkan siswa dalam belajar memecahkan masalah lingkungan hidup, sehingga pembelajaran lebih bermakna dan siswa dapat berpartisipasi dalam upaya menanggulanginya.

Selain itu, pembelajaran model ini membuat siswa tidak hanya memperoleh pengetahuan dengan cara mendengarkan penjelasan dari guru, tetapi mengkaitkan dengan informasi baru yang telah mereka dapatkan dari pembelajaran di luar kelas.

Siswa yang belajar di luar kelas lebih baik dibandingkan dengan siswa yang hanya belajar di dalam kelas. Hal tersebut disebabkan pembelajaran yang dilakukan di luar kelas membuat suasana belajar menjadi sangat menyenangkan. Kemendikbud menyatakan "outdoor study menciptakan suasana belajar yang menyenangkan dan siswa dapat mengkaji obyek sesungguhnya, sehingga siswa akan termotivasi untuk belajar dengan sungguh-sungguh. Siswa yang mempunyai motivasi yang baik, tentu akan mengikuti pembelajaran yang baik pula, sehingga hasil belajar yang diperoleh juga akan tinggi.

Pada kelas kontrol yang menggunakan metode ceramah dan diskusi kelompok tidak melakukan pembelajaran di luar kelas. Pembelajaran yang cenderung dilakukan di dalam kelas. Hal tersebut membuat siswa kurang berminat mengikuti pembelajaran. Akibatnya, hasil belajar yang diperoleh siswa cenderung kurang baik.
Kedua, hasil belajar IPS kelas eksperimen lebih tinggi karena siswa kelas eksperimen (outdoor study) lebih mampu mengintegrasikan materi yang diperoleh dengan permasalahan nyata di lapangan, sehingga dapat menyelesaikan pertanyaan post-test dengan baik dan benar. Selain itu, sumber belajar yang berasal dari konteks kondisi lingkungan siswa membuat perolehan hasil belajar lebih maksimal. Sejalan dengan Gage and Berlinar (1985) menyatakan bahwa pengamatan terhadap kejadian yang sungguh-sungguh terjadi di lapangan akan sangat bermakna bagi perolehan belanjar siswa.

Ketiga, kegiatan observasi lapangan yang dilakukan pada pembelajaran Outdoor Study meningkatkan keterampilan penalaran siswa. Keterampilan penalaran membuat siswa mampu menjawab pertanyaan yang membutuhkan penalaran dalam pemecahan masalahnya secara ilmiah. Hal tersebut akan membuat siswa memahami materi yang diberikan dan mengaitkan dengan permasalahan di lingkungan mereka, sehingga hasil belajar yang mereka peroleh tinggi. Lawson (1992) membuktikan bahwa keterampilan penalaran merupakan prediktor yang paling konsisten terhadap prestasi belajar dibanding variabel lainnya seperti gaya (style), kognitif, kapasitas mental, fluid intelegence.

Kegiatan outdoor study juga dapat meningkatkan motivasi belajar dan aktivitas siswa. Dorongan mental (motivasi) dan aktifitas fisik (keaktifan) akan berpengaruh langsung pada hasil belajar siswa. Ketiganya 
terdapat keterkaitan kuat. Karena hasil belajar merupakan puncak dari proses belajar mengajar (Dimyati dan Mudjiono, 1994:11). Tidak mengherankan hasil belajar Geografi pada kelas eksperimen lebih tinggi dibandingkan kelas kontrol yang hanya belajar di dalam kelas.

Keempat, pembelajaran Outdoor Study yang berpusat pada siswa menempatkan siswa sebagai subjek belajar, artinya siswa berperan aktif dalam pembelajaran dengan cara aktif bertanya, memprediksi, menjelaskan, dan berinteraksi dengan material konkret dengan menggunakan pengetahuan awal dan mengaplikasikanya dalam pengetahuan baru. Hal tersebut membuat hasil belajar siswa juga optimal.

Tercapainya hasil belajar yang optimal tersebut, tidak terlepas dari banyak pihak yang mendukung keterlaksanaan pembelajaran, salah satunya adalah peran guru. Selama pembelajaran IPS dengan outdoor study, guru telah menunjukkan tindakan-tindakan yang memang seharusnya dilakukan dalam pembejaran Outdoor Study, sehingga siswa dapat menyimpulkan pengetahuan yang didapatkannya. Hal tersebut sejalan dengan pendapat Hamzah (2012) bahwa "salah satu prinsip mengajar guru adalah harus menjaga konsentrasi belajar peserta didik dengan cara memberikan kesempatan berupa pengalaman langsung, mengamati/meneliti, dan menyimpulkan pengetahuan yang didapatkannya”.
Terdapat temuan tambahan dalam penelitian ini yang menarik untuk dibahas, sekaligus menjadi kelebihan dari pembelajaran Outdoor Study, yaitu: pertama, siswa eksperimen jauh lebih mampu dalam membuat karya tulis sederhana berupa catatan hasil kegiatan pada Kompetensi Dasar menunjukkan perilaku peduli, gotongroyong, tanggungjawab dalam berpartisipasi penanggulangan permasalahan lingkungan hidup. Hal ini terjadi, karena tahapan pembelajaran Outdoor Study benar-benar dilaksanakan secara matang dan sungguh-sunguh. Selain itu, pembelajaran Outdoor Study merupakan suatu pembelajaran yang berbasis masalah terhadap permasalahan nyata dan relevan bagi kehidupan siswa, sehingga sangat cocok sekali untuk mengkaji permasalahan pencemaran sampah di sekitar sekolah. Kedua, siswa lebih aktif dan antusias dalam mengikuti kegiatan pembelajaran. Pada saat pembelajaran mereka melakukan diskusi sangat aktif dalam menyampaikan pendapat mereka mengenai pencemaran sampah. Kajian pencemaran sampah yang ada disekitar mereka sangat menarik antusias siswa untuk berdiskusi dan mengutarakan pendapatnya.

Kelima, Pembelajaran Outdoor Study membuat siswa mampu menemukan konsep secara langsung dengan pengamatan di lapangan mengenai permasalahn lingkungan hidup disekitarnya. Pengumpulan informasi dilakukan melalui pengamatan langsung sesuai lembar kerja siswa yang diberikan. Lembar kerja siswa dipergunakan sebagai petunjuk pelaksanaan pengamatan yang berkaitan dengan materi 
permasalahan lingkungan hidup. Kegiatan tersebut akan meningkatkan kemampuan pemecahan masalah siswa. Seperti yang diungkapkan Thomas (2000: 4) menggolongkan "proses investigasi sebagai proses desain, pengambilan keputusan, penemuan masalah, pemecahan masalah, discovery, atau pembangunan model". Dengan demikian, aktivitas ini adalah transformasi dan konstruksi pengetahuan.

\section{Pelaksanaan pembelajaran Outdoor}

Study menuntut siswa mampu mengaplikasikan teori, keterampilan, dan teknik yang dipelajari untuk memecahkan permasalahan yang dekat dengan siswa. Pembelajaran seperti ini akan lebih bermakna, karena siswa terlibat langsung dalam proses perolehan konsep.

Keenam, kolaborasi dengan kelompok. Pembelajaran Outdoor Study menuntut siswa bekerja dalam kelompok atau tim. Kolaborasi dengan kelompok membuat mereka dapat bertukar ide atau pendapat untuk menyelesaikan permasalahan di sekitar merekan. Bekerja dalam kelompok akan menambah pengetahuan siswa. Tentu hal ini akan berpengaruh pada hasil belajar yang mereka peroleh. Semakin sering mereka bertukar pikiran, semakin baik pula perolehan hasil belajarnya. Teori-teori kognitif yang baru dan konstruktivistik menegaskan bahwa belajar adalah fenomena sosial, dan siswa akan belajar lebih di lingkungan kolaboratif.

Secara umum, pembelajaran outdoor study telah terbukti berpengaruh terhadap hasil belajar siswa MI. Namun, terdapat kelemahan dalam penelitian,yaitu membutuhkan waktu yang relatif lama. Selain itu, pembelajaran ini memerlukan perencanaan pengelolaan kelas yang baik dan terorganisasi, agar saat pelaksanaan pembelajaran tidak terjadi kebingungan dan tujuan pembelajaran dapat tercapai.

\section{KESIMPULAN}

Pembelajaran outdoor study berpengaruh terhadap hasil belajar IPS siswa MI. Hal ini dibuktikan dengan rata-rata gain score kelas eksperimen lebih tinggi dibandingkan kelas kontrol. Hal tersebut disebabkan pembelajaran Outdoor Study memberikan kesempatan pada siswa untuk menggali konsep secara langsung di lapangan dan mengelaborasikan dengan materi yang diberikan, sehingga kegiatan pembelajaran dapat dilaksanakan secara maksimal dan hasil belajar siswa tinggi.

Saran peneliti kepada guru bahwa sebelum melaksanakan pembelajaran Outdoor Study harus dipersiapkan secara matang. Hal tersebut bertujuan agar pada saat pembelajaran tidak ada siswa yang bingung dan pembelajaran dapat diselesaikan sesuai dengan waktu yang telah ditetapkan, sehingga tujuan pembelajaran dapat tercapai. Selain itu, guru menggunakan pembelajran ini sebagai variasi dalam mengajar guna meningkatkan hasil belajar IPS.

Saran untuk peneliti selanjutnya untuk menguji pengaruh pembelajaran Outdoor Study terhadap variabel, lokasi, jenjang pendidikan, dan materi yang berbeda. Pembelajaran Outdoor tidak harus diterapkan pada seluruh materiIPS, karena tidak semua materi IPS cocok dengan 
model ini. Selain itu, pembelajaran Outdoor Study ini membutuhkan waktu yang relatif panjang.

\section{DAFTAR PUSTAKA}

Dimyati. \& Mudjiono. 1994. Belajar dan Pembelajaran. Proyek Pembinaan dan Peningkatan Mutu Tenaga Kependidikan Dirjen Dikti, Jakarta: Dirjen Dikti.

Depdiknas. 2006. Standar Isi Untuk Satuan Pendidikan Dasar dan Menengah. Jakarta: Depdiknas.

Gage, N. L. \& Berliner, David C. 1985. Educational Psychology. New York: Gulf Publishing Company.

Hamzah, Uno. 2012. Orientasi Baru dalam Psikologi Pembelajaran. Jakarta: Bumi Aksara.

Kemendikbud. 2013. Model Pembelajaran Berbasis Proyek. Badan Pengembangan Sumber Daya Manusia Pendidikan dan Kebudayaan dan Penjaminan Mutu Pendidikan.
Lawson, Anton E. 1992. Development of Reasoning Among College Biology Student. V-A Review of Research. JCST: Vol. XX1 (6) May: 338344.

Nurhadi. 2002. Pendekatan Kontekstual (Contekstual Teaching and Learning). Malang: Universitas Negeri Malang.

Rostana, E. Cecep. 2002. Pembelajaran dan Pengajaran Kontekstual. Jakarta: Departemen Pendidikan Nasional Direktorat Jenderal Pendidikan Dasar daTI Menengah Direktorat Sekolah Lanjutan Pertama.

Sumarmi. 2012. Model-Model Pembelajaran Geografi. Yogyakarta: Aditya Media Publishing

Susilo, H. 2001. Pembelajaran Kontekstual untuk Meningkatkan Pemahaman Siswa. Makalah disampaikan pada Seminar Pembelajaran dengan Filosofi Konstruktivisme. Jombang, 22 September

Thomas, J. W. 2000. A Review of Research On Project Based Learning. Supported by The Autodesk Foundation 111Mclnnis Parkway San Rafael, California. (Online), (http://www.autodesk.com/foundation), diakses tanggal 26 April 2016. 